Beyond Philology No. 16/2, 2019

ISSN 1732-1220, eISSN 2451-1498

https://doi.org/10.26881/bp.2019.2.05

\title{
Justification of multiple ecofeminist perspectives: Diversity really matters
}

DANICA MILOSEVIC

Received 31.01.2018, received in revised form 22.11.2018, accepted 30.11.2018.

\begin{abstract}
Ecofeminism has grown, developed and transformed itself as a theory and made progress to encompass many different philosophical stances today. Cultural, social and radical ecofeminism are just some of the forms that ecofeminism can currently take. All of these sources of knowledge have contributed immensely to ecofeminist thought in general, although they have often been confronted by and supportive of different epistemologies. For instance, cultural ecofeminists have been accused of being essentialist. On the other hand, social ecofeminists relying on constructionism, as opposed to essentialism, have fiercely attacked capitalism as well as other isms (like classism, racism, sexism) aiming at the pillars of power upon which patriarchal society is constructed. This paper will try to reconcile the said opposing ecofeminist theories and highlight their importance in the development of ecofeminist perspectives. It will give an overview of ecofeminist viewpoints and show how they can be complementary.
\end{abstract}

\section{Keywords}

dualism, essentialism, constructionism, ecofeminism 


\title{
Uzasadnienie dla mnogości perspektyw ekofeministycznych - różnorodność naprawdę ma znaczenie
}

\begin{abstract}
Abstrakt
Współczesna teoria ekofeministyczna przeszła transformację, rozwinęła się i rozrosła, wskutek czego obecnie obejmuje wiele podejść filozoficznych. Ekofeminizm kulturowy, społeczny i radykalny to tylko niektóre $z$ form, które przybiera ten nurt. Wszystkie wyżej wymienione źródła wiedzy przyczyniły się do myśli ekofeministycznej, mimo że często wchodziły w polemikę, bądź też popierały, różne epistemologie. Na przykład reprezentanci kulturowego ekofeminizmu byli oskarżani o nadmierny esencjalizm. $Z$ kolei przedstawiciele ekofeminizmu społecznego, który, w przeciwieństwie do esenjalizmu, oparty jest na konstruktywizmie, zajadle atakuja kapitalizm i inne -izmy (klasycyzm, rasizm, seksizm), mierzac w filary władzy, na których zbudowany jest patriarchat. Niniejszy artykuł stanowi próbę pogodzenia teorii ekofeministycznych i podkreśla ich znaczenie w rozwoju różnych perspektyw. Zaproponuje przegląd stanowisk ekofeministycznych i pokaże, że mogą się uzupełniać.
\end{abstract}

\section{Słowa kluczowe}

dualizm, esencjalism, konstrukcjonizm, ekofeminizm

One of the founders of ecofeminist theory, the American theoretician and activist Ynestra King (1989: 120) defined ecofeminism as "a global movement that is founded on common interests yet celebrates diversity and opposes all forms of domination and violence". This has been the guiding principle of ecofeminism since its conceptual development in the mid-seventies of the $20^{\text {th }}$ century till the present day. From the outset, ecofeminism has clearly stated that its goal is to question the injustices imposed by (1) the patriarchal regime (Starhawk 1999), (2) capitalism as the product of patriarchal society (Merchant 1995, Shiva 1993), and (3) patriarchal ideological 
structures such as essentialism and dualism (Carlassare 1994, Warren 1996, 1997).

Dualism was introduced as a theoretical framework in ancient Greece by the philosophers Plato and Aristotle. Both of them saw the body and the soul as different and opposing categories. Aristotle treated the soul as one form of the body, "not a separate substance", and in this way managed to explain the presence of the soul in the body (Robinson: 2003). Unlike Aristotle, Plato separated the body from the soul by stating that "soul is a true Form", or "real substance" belonging to the superior immaterial realm, while the body was just a copy of this Form in the physical realm (Robinson: 2003). Rene Descartes, the French philosopher who remodeled the concept of dualism in the period of classicism, envisaged in his Cartesian dualism two different types of substances, "minds or thinking substances and bodies or corporeal substances" (Barker \& Morris 2005: 22). Descartes was of the opinion that the mind and the body could interact under divine intervention and that the body operated like a mechanism according to its inner laws (Robinson: 2003). Levi-Strauss, a French anthropologist and structuralist also made a significant contribution to the system of dualistic thought. For him binary oppositions were "the basic structure of all human cultures, all human ways of thought, and all human signifying systems" (Mary Klages 2013: 2). Levi-Strauss made it clear that human culture and language are structured on binary pairs of opposites, where one term is always favored over the other. However, he was not so interested in the individual qualities of units, "but the relation between any two units compared in a binary pair" (Mary Klages 2013: 2). Aware of the discrepancies within the field of dualism, ecofeminists have attacked its core, that is, the insistence of dualism on the division of entities into binary oppositions, the creation of hierarchical relations, the imposition of a logic of domination and the underestimation of certain concepts.

The idea that phenomena in the world are divided into two opposing categories, by which process some entities are treat- 
ed as superior while others are seen as inferior, or less valuable than their counterparts, has led the ecofeminists to embark on a project in order to impose the principles of equality, partnership and promotion of diversity through their work. Sandilands (1999: 195) qualifies this ecofeminist endeavor as "holistic understanding" which "emphasizes the interconnections among various aspects of human and non-human life", thus creating unity of the biotic and abiotic, necessary for the sustainability of life on planet Earth.

Value dualisms, i.e., disjunctive pairs, are seen "as oppositional (rather than as complementary), and exclusive (rather than as inclusive)" (Warren 1996: 20-21) through the ecofeminist lens. Val Plumwood (Warren 1997: 337-338), an Australian ecofeminist, noticed that there are five techniques behind the ideology of dualism that have been central to the maintenance of patriarchal stability in the modern culture of western society. These techniques are radical exclusion, denial, incorporation, instrumentalism, and homogenization. They are practiced by patriarchal authorities who use them to impose hegemony, exercise control, and strengthen their power over women, nature and animals. Thanks to these techniques male individuals and male virtues become the carriers and symbols of power that take central position in the patriarchal structure, while other non-male entities are pushed towards the margins and qualified as worthless, insignificant and imperfect. Thus, only that which demonstrates the male principle itself becomes important for shaping our reality. Even when a common feature is recognized in opposing concepts, this feature is seen as more representative in the concept that is defined by its malelike qualities. This leads to incorporation which creates a clear distinction between the entities that are above as superior, and the entities that are below as subordinate. In such a structure, the woman is "defined in relation to the man as central", not as "an autonomous being" (Plumwood in Warren 1997: 338). Nature is "perceived as disorder, as unreason, to be replaced where possible by human order in development, an assimilating project of colonization" (Plumwood in Warren 1997: 341). 
All the entities that do not have a significant instrumental value are then considered irrelevant to patriarchal society since they cannot bring any concrete material benefit to it. Finally, the process of homogenization imposes the idea that non-male entities are perceived as non-specific and similar to one another, which gives justification for their classification under one category labeled as the other. This category eventually "becomes the repository of the bad, the mirror reflection of the good", or that which is discarded, neglected and oppressed by patriarchal authority (Sandilands 1999: 141). According to Lisa Kemmerer (2013), in patriarchal society women, people of color, children and the poor become "human Others", while animals, forests and the land turn into "earth Others".

This logic of domination hidden behind the concept of dualism assigns the central position to the male individual in patriarchal culture, confirms the hegemony of the male principle and deepens the gap between dichotomies such as center/margin, master/slave, and subject/object. Ecofeminism strongly objects to such divisions with a special focus on dichotomies such as man/woman, culture/nature, or man/ animal. Such binary oppositions support the andro-centric idea that man is superior to and dominant over woman, nature, and animals, asserting that these entities need to be oppressed, manipulated and exploited in the name of male culture, which sees them as insignificant and powerless.

Through its effort, ecofeminism has shown the opposite. Unlike dualism which rejects what is different, ecofeminism embraces difference as something that is unique, valuable and significant. Ecofeminism pays respect towards each entity regardless of its instrumental value, putting focus solely on the inherent values that different entities possess, thereby disregarding any hierarchical value structures (Starhawk 1999).

Over the last four decades ecofeminism has expanded its epistemology to include liberal, radical, socialist, queer, native, cultural and social ecofeminism. All of these different streams of thought have managed to keep one thing in common and that is the determination to bring harmony to the dualistic way 
of thinking, by promoting the ideas of tolerance, egalitarianism and justice, revealing the aggressive, violent and destructive practices of patriarchy along the way. Even if these forms of ecofeminism rely on different means, they still strive to achieve the same goal of ecofeminism, which is to recognize the value and importance of both woman and nature, and halt the processes by which woman and nature are marginalized, discriminated against and maltreated by western patriarchal society. Each form is, however, regarded as unique and valuable, since it gives a different perspective on ecofeminism as a theory.

Liberal ecofeminism is concerned with the laws and regulations that can protect both women and nature from a patriarchal practice that is harmful and destructive. Aware of the ecological crisis, liberal ecofeminism, "deals with the problems of the failure to regulate pesticides and other environmental pollutants" in view of the increasing consciousness of malicious agricultural and industrial practices that have a negative effect on nature and the health of people. Therefore, the grounds of liberal ecofeminism can be regarded as a political arena for women who are invited to give their full contribution to environmental protection and conservation of natural resources, while also claiming along the way, greater human rights for themselves (Merchant 1995: 9-10). Therefore, the concerns of liberal feminists encompass not only issues related to the well-being of the planet and non-human animals, but also issues of female needs, rights and freedoms that are still silenced, curbed and restricted by patriarchal laws. Although one era of emancipation has been completed (in the 1960s), emancipation as a whole is still needed to win justice for women who suffer from the oppression of the patriarchal regime in different ways. Karren Warren, therefore, (1996: 5) claims that the "liberation of women cannot be achieved until all women are liberated from the multiple oppressions that structure our gendered identities: women of colour from racism, poor women from classism, lesbian women from heterosexism, young and old women from ageism, Jewish women from anti-Semitism, women of the South from ethno-centrism". Therefore, liberal 
ecofeminism advocates for the multiplicity of female voices that need to be heard, recognized, given the right of speech and appreciated in the political discourse.

Radical ecofeminism protests against patriarchal society and capitalism in order to find ways in which it is possible to struggle against the oppression of the patriarchal regime and liberate both woman and nature from the hardships of civilized society. Its approach is similar to that of liberal ecofeminists, but it asks for a more direct struggle and concrete acts of defiance "to dismantle those very structures" of patriarchy (Merchant 1995: 207).

Socialist ecofeminism "focuses on the relationship between production and reproduction and on women's work in the continued biological and social reproduction of life on Earth" to see how this reflects on the welfare of women and the natural environment in the capitalist paradigm (Merchant 1995: 207). It protests against reducing females to their reproductive role, and at the same time against exploiting female beings as a labor force. The latter especially refers to the domain of housework where women are treated as shadow workers responsible for chores that do not have any economic value and therefore need not be paid for or given any credit.

Queer ecofeminism supports the rights of the LGBT population, whose sexual behavior is labeled by different stigmas in a modern patriarchal culture which is homophobic. Greta Gaard (1997), a German ecofeminist, does not see homosexuality as an unnatural act. To her, the problem lies in patriarchal culture which has constructed the standards for acceptable sexual behavior and sees homosexuality as "trans-gressive in at least three categories: as acts against biblical morality, against nature or against psychology" (Gaard 1997: 141). Through patriarchal practice, queer identities are reduced only to their abnormal and perverse erotic aspect, which is seen as their "only salient feature". This way, patriarchy devalues, underestimates and depreciates the other aspects of queer personality, annihilating other human qualities in queer individuals (Gaard 1997: 139). 
Native ecofeminism states that it is necessary to "live close to nature, nurturing sacred lands and re-consecrating degraded spaces" through a determination to cherish the traditional values and principles of ancient communities which lived in harmony with nature and treated land as a sacred ground (Merchant 1995: 207).

In a similar spiritual way, cultural ecofeminism "celebrates the relationship between women and nature through the revival of the ancient rituals centered on goddess worship, the moon, animals, and the female reproductive system" (Merchant 1995: 11). It draws its strength from the religion of the Great Goddess that inspires women to treat their bodies as sacred and their mother role as divine in celebration of life, nature, natural laws, cosmological oneness and unity in diversity. According to Merchant (1995: 11), "cultural ecofeminist philosophy embraces intuition, an ethic of caring, and web-like human-nature relationships" treating all entities as interconnected, mutually dependent and inseparable from nature as a whole. It insists on partnership with nature and the ethical behavior of each individual towards his/her natural surroundings in view of conservation of natural resources, encouragement of life affirming activities and the celebration of diversity which "assures survival and continuing evolution" and is therefore essential for the sustainability of life (Starhawk 1999: 219).

Social ecofeminism, on its part, starts with the idea that "dominating nature stems from the domination of human by human" (Merchant 1995: 13). Therefore, the main task of social ecofeminism is to eradicate all forms of hegemony in patriarchal culture that are responsible for the construction of a hierarchical society. This means that all forms of -isms have to be abolished - especially those constituting sexism, racism, classism, naturism or ageism. Moreover, social ecofeminism restructures the "oppressions imposed on women by marriage, the nuclear family, romantic love, the capitalist state, and patriarchal religion" (Merchant 1995: 14). Therefore, social ecofeminism tends to introduce changes in the patriarchal dis- 
course out of a constructivist belief that language has the power to alter our reality and redefine ideologies that are guiding our everyday lives. It claims that dualism, as a social construct, that is, a product of patriarchal society can be, if not deconstructed, then at least modified, to establish a new discourse infused with new meanings and values that take voices of women and nature into account.

However, there have been some serious disputes among certain theoreticians within the ecofeminist framework. Namely, ecofeminists have started a debate concerning the level of implication of cultural ecofeminism in essentialism, which is another patriarchal ideology that has significantly influenced the distribution of power in favor of patriarchal authority. Essentialism "usually refers to the assumption that a subject is constituted by pre-social, innate, unchanging qualities" (Carlassare 1994: 221). It assigns permanent qualities or essences to different objects which thus become once and for all labeled by patriarchal stereotypical ways of thinking. Plato was the first philosopher who introduced essentialism and established eidas or essences as defined, constant, and unchangeable qualities that cannot be transformed (Delamater $\&$ Hyde).

In essentialism women and nature are perceived as known categories that are determined by their most conspicuous features. For instance, essentialists regard woman as a sensitive, emotional, hysterical and less intellectually endowed being, but most importantly as a reproductive being that has the capacity to give birth to children. Woman gets reduced to the physical aspect of herself, since her biological reproductive potential is considered to be her greatest value for patriarchal society. As Shiva (1993: 24) points out "reductionism also reduces complex ecosystems to a single component, and a single component to a single function". Nature, which woman is identified with through the analogy of reproduction, is also reduced to its capacity to yield, nurture, feed, shelter and provide for the civilized man whose appetites for her resources never get satisfied. Therefore, in essentialism, nature resembles woman in her mother-like qualities to bring forth new life, 
while woman experiences nature as a space close to her sensibility that she can understand, sympathize with, live in harmony with and rely on.

Cultural ecofeminism, in fact, takes over only some ideas from essentialism and not the entire concept; therefore, it cannot be labeled as purely essentialist as some ecofeminists would like to contend. Among other claims, essentialism states that women and nature are tied to each other with special bonds. This idea is the only one that cultural ecofeminists find appealing. By no means does cultural ecofeminism try to internalize essentialist reductionism in order to simplify the identity of both women and nature and underestimate their integrity. Cultural ecofeminists are fully aware that "reductionist science is a source of violence against nature and women, in so far as it subjugates and dispossesses them in their full productivity, power and potential"(Shiva 1993: 24). Cultural ecofeminism rather, defies reductionism out of a belief that both woman and nature have various aspects that are praiseworthy and that should be respected and given recognition. In the religion of the Goddess "all people are already seen as manifest gods, and differences in color, race, and customs are welcomed as signs of the myriad beauty of the Goddess" (Starhawk 1999: 38). Therefore, the maintenance of the woman/nature relationship and respect to the affairs of the Great Goddess are perceived as quintessential to survival for both women and nature in cultural ecofeminism. As one of the leading cultural ecofeminists Starhawk (1999: 34) claims "Through the Goddess, we can discover our strength, enlighten our minds, our own bodies, and celebrate our emotions. We can move beyond narrow, constricting roles and become whole". The strength of woman lies in her relationship with nature and her interconnectedness with the entire organic world in which the Goddess herself is imminent. Cultural ecofeminism therefore empowers women whose voices are silenced in patriarchal culture, and helps them to realize their full potential by recognizing the divine capacity in them. For cultural ecofeminists the connection between nature and wo- 
men is seen as "a source of spiritual empowerment and political activism", the Goddess being the symbol of female power, experience, wisdom, creativity and political awareness (Chopin in Klein 2000: 3). More importantly, this connection is not considered as a by-product of patriarchal intervention, but rather as an inner guiding principle of female survival, something that women desire themselves and find satisfying in practice.

Social ecofeminists, however, refuse to accept the idea that woman and nature can be permanently defined by their essences. They claim that "Neither of the two entities have either innate essences or an essential connection" (Carlassare 1994: 223). In their opinion, both woman and nature are categories prone to change, development, transformation and growth. Therefore, it is impossible to define woman and nature as monolithic categories. It is their belief that "celebrations of the "feminine role", the "feminine principle", the "feminine values" of goddess spirituality homogenize and essentialize women, equating sex and gender while erasing critical differences like race and class" (Gaard 2011:36).

Women differ from one another through their racial, social, sexual, religious and other backgrounds. Ecosystems differ from one another, so that the concept of nature in one culture or nation is different from the concept of nature in another culture or nation. Therefore, social ecofeminists urge the deletion of any possible analogies between women and nature that patriarchy imposes. By rejecting essentialism, social ecofeminism actually attempts to break the ties between women and nature, convinced that this relationship is another product of patriarchal culture or another social construct. In this school of thought, essentialism has been accused of "the exploitation of nature and animals ... by feminizing them" and "the exploitation of women .... by naturalizing them" (Warren 1997: 12).

Carolyn Merchant (1995), a social ecofeminist, states that woman is treated as a being closer to the natural environment in patriarchal culture, not because she has greater empathy towards natural processes, but due to her traditional social 
roles that have confined her to the private space of her home and limited her activities to the ones around the house. These traditional roles of the housewife and the mother have made women more attached to the environment, which has resulted in more sophisticated female competences in interaction with nature. This woman/nature link is thus an outcome of different historical, economic and political factors that have left a mark on the lives of women and their stereotypical roles in culture. "The implication is that women are not necessarily more natural than men but the conditions of their existence allow them to know nature in different ways than men", explains Sandilands (1999: 24). Man in patriarchal society, on the other hand, is associated with culture as its creator, representative and defender, and therefore the values that he represents contradict the ones that are specific for women and nature. The dichotomy man/culture is far too superior to the dichotomy women / nature. In such a mutual relationship, as it seems "woman serves the interests of a man", while "nature ... is sacrificed to culture" (Madsen 2000: 124).

Cultural ecofeminists such as Ynestra King, Starhawk, Susan Griffin, Cathleen McGuire, and Colleen McGuire insist on the relationship between women and nature out of a belief that woman can gain strength in contact with nature and switch to her active state of mind. Unification with the Goddess and nature is an "inner journey, a personal vision quest, a process of self-healing and self-exploration" (Starhawk 1999: 225). According to these cultural eco-feminists, woman can draw energy from her natural environment to survive, oppose, and even fight patriarchal authority. "For women, the Goddess is the symbol of the inmost self, and the beneficent, nurturing, liberating power within woman" (Starhawk 1999: 111). Such ecofeminists turn to spiritualism, rituals that are performed in praise of nature and the Goddess, believing that the further survival of women and nature in patriarchal society depends on forgotten matriarchal beliefs suppressed by patriarchal culture, which has for a long while been stricken by the process 
of denaturalization, that is, a systematic alienation from nature.

Although there seems to be a great difference in the attitudes of social and cultural ecofeminists, there are also certain similarities in these two opposing theories which indicate that social and cultural ecofeminism do not have to be exclusive, but rather supportive of one another. Both theories, even if contradictory, share the same logic of ethics and care. As a result, they can make a huge contribution to ecofeminist thought through joint effort. According to Merchant (1995: 216-217) "a partnership ethic of earth care means that both women and men can enter into mutual relationships with each other and the planet independently of gender and does not hold women alone responsible for "cleaning up the mess" made by male-dominated science, technology and capitalism". This idea finds its applicative use in both social and cultural ecofeminisms, since they both insist on the fact that it is not only women but the entirety of humanity that is responsible for protecting the natural environment and finding an appropriate pace for technological development. As Plumwood (in Sandilands 1999: 140) says "both men and women are both part of nature and culture. Both men and women can stand with nature and work for breaking down the dualistic construction of nature". Shiva (1993) also supports this viewpoint and provides a good example by combining both social and cultural teachings in her work. She attacks western society for its corruption, consumerism and merciless capitalist production, in an attempt to criticize patriarchal constructs and practices. Simultaneously she praises the Goddess culture of the East, paying tribute to her Indian cultural background, therefore making a perfect balance between the doctrines of social and cultural ecofeminism.

It should be noted that although cultural ecofeminism promotes a woman/nature relationship, it does not exclude from its programme male intervention that is guided by the principles of love, life, creativity, respect towards nature and harmonious interaction with it. Therefore, both female and male en- 
gagement in the process of environmental protection is expected and encouraged through cultural ecofeminism that rests on the ecological assumption that all living beings are interconnected and dependent on one another and therefore required to act justly and ethically towards their environment. The theories of both social and cultural ecofeminism rely upon the logic of ethics and, in fact, share four precepts that Merchant (1995: 217) solely assigns to social ecofeminism. These are: 1. equality between human and non-human communities, 2. moral consideration for humans and non-human nature, 3. respect for cultural diversity and biodiversity, and 4. inclusion of women, minorities, and non-human nature in the code of ethical accountability. Throughout the ethics of care once again, it is established that the principle of equality is the most important in both ecofeminist fractions. Woman, animals and nature are not to be treated as the other, but as equals to man and his culture, with equal rights to justice. Diversity seen as both cultural diversity and biodiversity is the second idea central to both theories. In cultural ecofeminism diversity is promoted through celebration of various aspects of the Goddess who is to be found in our deepest, inner selves as well as the natural world which is sacred. To Starhawk (1999: 36) "serving the life force means working to preserve the diversity of natural life, to prevent the poisoning of the environment and the destruction of species".

In social ecofeminism diversity is celebrated through reaffirming the value of all the oppressed human and non-human beings and their inclusion in the patriarchal reality in which patriarchal practices such as racism, classism, sexism, naturism and ageism are deeply shaken and thoroughly questioned.

Although social ecofeminists believe that the naturalization of women and the feminization of nature only deepen the repressed position of women and nature in culture, cultural ecofeminists see the relationship between women and nature, diametrically opposite, as crucial both for the survival of women and the survival of nature. For cultural ecofeminists, birth is a sacred act, a new life that is celebrated and glorified as 
a special, divine gift that a woman possesses, therefore, it cannot be regarded as a simple reproductive function. Starhawk (1999: 158) says: "We say that our bodies are sacred, because they bring forth life, because they are life, because they give us pleasure, because with them we make, build, think, laugh, create and do".

The act of giving new life guarantees the continuation of the human race and the survival of humans on planet Earth, which constantly passes through the cycles of birth, death and regeneration. It is precisely in this creative role that cultural ecofeminists recognize the power of women, and even their potential for subversive action inspired by the worship of the Great Goddess, around whose aura the female collective is united. Having such a life-promoting engagement in mind, it is unfair to exclude cultural ecofeminism as an unsuitable doctrine that is involved in essentialism or that gives support to many of the patriarchal techniques that are destructive towards woman and nature.

As the ecofeminist movement gives support to cultural diversity and biodiversity, ecofeminism itself should nurture a pluralism that takes into account different attitudes, opinions and beliefs since they are all, no matter how diverse, part of the ecofeminist mosaic that is much more vivid and prolific when the polyphony of its voices can be heard. This also includes cultural ecofeminism.

\section{References}

Barker, Gordon, Katherine Morris (2005). Descartes's Dualism. London: Routledge.

Carlassare, Elizabeth (1994). "Essentialism in ecofeminist discourse". In: Carolyn Merchant (ed.). Ecology. New York: Humanities Press, 220-234.

Gaard, Greta (1997). "Toward a queer ecofeminism". Hypatia 12/1: 137-155. 
Gaard, Greta (2011). "Eco-feminism revisited: Rejecting essentialism and re-placing species in a material feminist environmentalism". Feminist Formations 23/2: 26-53.

Kemmerer, Lisa (2013). "Ecofeminism, women, environment, animals". DEP 23: 66-73.

King, Ynestra (1989). "Healing the wounds: feminism, ecology, and nature/culture dualism". In: Alison M. Jaggar and Susan Bordo (eds.). Gender/body/knowledge. New Brunswick: Rutgers University Press, 115-141.

Klages, Mary (2013). “The 'Structural Study of Myth' and other structuralist ideas". Available at <http://www.colorado.edu/English/ engl2010mk/levistrauss.2001.htm>. Accessed 3.7.2018.

Klein, Sarah (2000). Kate Chopin's Ecofeminism. Available at $<$ https: //www.womenwriters.net>. Accessed 15.06.2018.

Madsen, Deborah (2000). Feminist Theory and Literary Practice. London: Pluto Press.

Merchant, Carolyn (1995). Earthcare: Women and the Environment. New York: Routledge.

Mies, Maria, Vandana Shiva (1993). Ecofeminism. Halifax, Nova Scotia: Fernwood Publications.

Robinson, Howard (2003). "Dualism". In: Edward N. Zalta (ed.). The Stanford Encyclopedia of Philosophy. Available at <https:// plato.stanford.edu/archives/fall2017/entries/dualism/>. Accessed 7.07.2018.

Sandilands, Catriona (1999). The Good-Natured Feminist: Ecofeminism and the Quest for Democracy. Minneapolis: University of Minnesota Press.

Starhawk (1999). The Spiral Dance: A Rebirth of the Ancient Religion of the Great Goddess. New York: Harper One.

Warren, Karen (1997). Ecofeminism: Women, Culture, Nature. Bloomington and Indianapolis: Indiana University Press.

Warren, Karen (1996). Ecological Feminist Philosophies. Bloomington and Indianapolis: Indiana University Press. 
Danica Milosevic

ORCID iD: 0000-0002-9271-7759

College of Applied Technical Sciences

Nis

20 Aleksandra Medvedeva

$18000 \mathrm{Nis}$

Serbia

danicamil@yahoo.com 